\title{
Tissue Remodeling in Vascular Wall in Kawasaki Disease-Related Vasculitis Model Mice
}

\author{
Yukako Yoshikane, Mitsuhisa Koga, Tamaki Cho, Kyoko Imanaka- \\ Yoshida, Yumi Yamamoto, Junichi Hashimoto, Hiroki Aoki, Koichi \\ Yoshimura, and Shinichi Hirose
}

\author{
Keywords \\ Kawasaki disease • Tenascin-C • c-Jun N-terminal kinase • Aneurysm • \\ Remodeling
}

Kawasaki disease is the most common acute systemic vasculitis of unknown etiology in children [1] and can cause inflammation of the coronary arteries leading to aneurysms. Tenascin- $\mathrm{C}$, an extracellular matrix protein, and c-Jun N-terminal kinase (JNK), an intracellular signaling protein, are known to be associated with inflammation and tissue remodeling [2, 3]. The purpose of this study was to demonstrate tenascin-C and JNK might be involved in tissue remodeling in a Candida albicans-induced murine model of aneurysm.

Y. Yoshikane $(\bowtie) \cdot K$. Yoshimura $\bullet$ S. Hirose

Department of Pediatrics, Faculty of Medicine, Fukuoka University, Nanakuma 7-45-1, Jonan-ku, Fukuoka 814-0180, Japan

e-mail: yyoshika@fukuoka-u.ac.jp

M. Koga

Department of Pharmaceutical Care and Health Sciences, Fukuoka University, Fukuoka, Japan

T. Cho

Department of Functional Bioscience, Fukuoka Dental College, Fukuoka, Japan

K. Imanaka-Yoshida

Department of Pathology and Matrix Biology, Mie University Graduate School of Medicine, Tsu, Japan

Y. Yamamoto • J. Hashimoto

Department of Surgery and Clinical Science, Yamaguchi University Graduate School of Medicine, Yamaguchi, Japan

H. Aoki

Cardiovascular Research Institute, Kurume University, Kurume, Japan

T. Nakanishi et al. (eds.), Etiology and Morphogenesis of Congenital Heart Disease, DOI 10.1007/978-4-431-54628-3_33 
1. More than $80 \%$ of the mice showed the macroscopic features of aneurysms in the aorta and/or iliac and coronary arteries.

2. Marked inflammatory cell infiltration was observed in vascular wall and perivascular connective tissue, accompanied by fragmentation of elastic fibers.

3. Expression of tenascin- $\mathrm{C}$ was highly observed in vascular wall, accompanied by active degradation of elastic fibers.

4. Pharmacologic inhibition of JNK attenuated the aneurysm formation in the mice model.

In conclusion, these findings suggest that both tenascin-C and JNK are involved in abnormal tissue remodeling and inflammation in the Candida albicansinduced Kawasaki disease murine model of aneurysm and that JNK inhibition may represent a novel therapeutic target for preventing a Kawasaki disease-related aneurysm.

Open Access This chapter is distributed under the terms of the Creative Commons AttributionNoncommercial 2.5 License (http://creativecommons.org/licenses/by-nc/2.5/) which permits any noncommercial use, distribution, and reproduction in any medium, provided the original author(s) and source are credited.

The images or other third party material in this chapter are included in the work's Creative Commons license, unless indicated otherwise in the credit line; if such material is not included in the work's Creative Commons license and the respective action is not permitted by statutory regulation, users will need to obtain permission from the license holder to duplicate, adapt or reproduce the material.

\section{References}

1. Kawasaki T, Kosaki F, Okawa S, Shigematsu I, Yanagawa H. A new infantile acute febrile mucocutaneous lymph node syndrome (MLNS) prevailing in Japan. Pediatrics. 1974;54:271-6.

2. Imanaka-Yoshida K. Tenascin-C in cardiovascular tissue remodeling: from development to inflammation and repair. Circ J. 2012;76:2513-20.

3. Yoshimura K, Aoki H, Ikeda Y, Fujii K, Akiyama N, Furutani A, Hoshii Y, Tanaka N, Ricci R, Ishihara T, Esato K, Hamano K, Matsuzaki M. Regression of abdominal aortic aneurysm by inhibition of c-Jun N-terminal kinase. Nat Med. 2005;11:1330-8. 